\author{
抗菌性フィルムドレッシング材が中心静脈カテーテル挿入患者の \\ 刺入部皮膚細菌叢に与える影響
加藤由紀子 ${ }^{1)} \cdot$ 浜田 幸宏 $^{1)} \cdot$ 久留宮 愛 $^{1)} \cdot$ 岡前 朋子 ${ }^{1)} \cdot$ 高橋 知子 ${ }^{1)}$

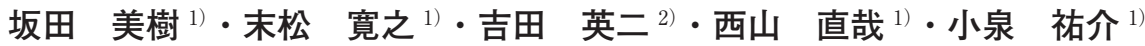 \\ 山岸 由佳 $^{1)} \cdot$ 三鴨 廣繁 ${ }^{1)}$
}

\title{
Antimicrobial Effect of Film Dressing for Skin around the Catheter Insertion Site
}

\author{
Yukiko KATO ${ }^{1)}$, Yukihiro HAMAdA ${ }^{1)}$, Ai KurumiYA ${ }^{1)}$, Tomoko OKAMAE ${ }^{1)}$, Tomoko TAKAhAShi ${ }^{1)}$, \\ Miki SaKATA ${ }^{1)}$, Hiroyuki Suematsu' ${ }^{1}$, Eiji YoshidA ${ }^{2)}$, Naoya NishiYAmA ${ }^{1)}$, Yusuke Koizumi ${ }^{1}$, \\ Yuka YAMAGISHI ${ }^{1)}$ and Hiroshige MiKAMO ${ }^{1)}$
}

${ }^{1)}$ Department of Infection Control and Prevention, Aichi Medical University Hospital, Aichi, Japan, ${ }^{2)}$ ALCARE Co., Ltd, Tokyo, Japan

(2016 年 6 月 10 日受付 $\cdot 2017$ 年 1 月 6 日受理)

\begin{abstract}
要 旨
中心静脈カテーテル関連の血流感染の約半数に刺入部周辺の皮膚の細菌が関連していることが明 らかになっている。我々は, 抗菌効果のある亜鉛結合繊維パッドを組み合わせたフィルムドレッシ ング（フィックスキット・CV）材が，中心静脈カテーテル刺入部周辺部の皮膚細菌叢に与える影 響を検討した。

同意を得た症例にフィックスキット ${ }^{\circledR} \cdot \mathrm{CV}$ と非亜鉛含有ドレッシング材の 2 種類を無作為に割 り付け, ドレッシング材除去直後にカテーテル刺入部周囲皮膚の $1 \mathrm{~cm}^{2}$ 範囲を滅菌綿棒でぬぐい取 り，細菌定量培養を実施した。フィックスキット ${ }^{\circledR} \cdot \mathrm{CV} 102$ 例，非亜鉛含有ドレッシング材 100 例 にて検討した．菌検出率は，それぞれ $47.1 \%$ (48 件), $62.0 \%$ （62 件）であった（ $p=0.03)$.ロジ スティック解析にて菌検出に影響を及ぼす因子は, BMI, 性別, カテーテル挿入部位であった. BMI $25 \mathrm{~kg} / \mathrm{m}^{2}$ 以上と BMI $25 \mathrm{~kg} / \mathrm{m}^{2}$ 未満での菌検出率は, それぞれ $73.8 \%, 49.4 \%$ であった $(p=0.01)$. 中心静脈カテーテル刺入部周辺部皮膚の細菌数は, BMI が大きく影響していた. BMI $25 \mathrm{~kg} / \mathrm{m}^{2}$ 未 満の患者では, 抗菌作用を有するドレッシング材を使用することにより皮膚細菌の増殖リスクが軽 減する可能性が示唆された.
\end{abstract}

Key words : 抗菌性フィルムドレッシング材, 中心静脈カテーテル, 皮膚細菌叢

\section{序文}

血管内留置カテーテルに関連した血流感染は, 医療費 の増加および入院期間の延長の原因となる重要な医療関 連感染である ${ }^{1,2)}$.

血管内留置カテーテル関連血流感染症 (catheter related blood stream infection : CRBSI) に関連する要因 は多岐にわたるが，それらが複合的にかかわることによ り感染が成立する。一般に, CRBSI の微生物侵入経路 は, 挿入部からの侵入 (患者自身の皮膚常在菌), カテー

1) 愛知医科大学病院感染制御部, 2)アルケア株式会社
テル接続部（医療従事者の手からの皮膚常在菌）, 輸液 (環境細菌）とされている ${ }^{3-8)}$.

このうちのカテーテル挿入部からの侵入は, CRBSI の $45 \%$ を占め, カテーテル挿入部周囲皮膚の細菌数の 増加とカテーテル細菌污染には相関があるとの報告があ る ${ }^{7,9)}$. また, 皮膚やカテーテル接続部から検出された細 菌と血流から検出された細菌の genotype の相同性が PFGE で一致したとの報告もある ${ }^{10)}$. これらのことから， カテーテル扦入部の皮膚の細菌数を減少させることによ

り CRBSI を減少させうると考えられている ${ }^{328.16)}$. 本邦において, 無機系抗菌物質である亜鉛を綿繊維に 


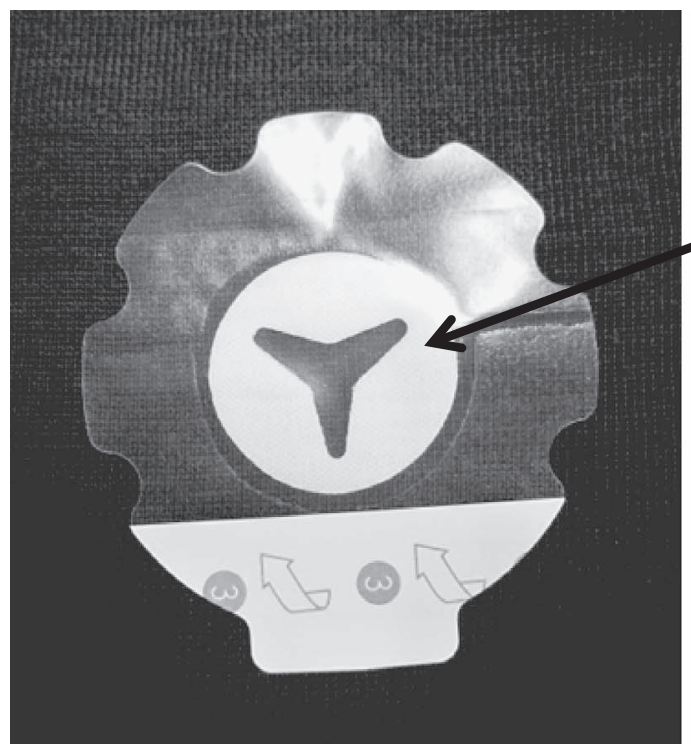

\section{亜鉛化合物含有綿織物}

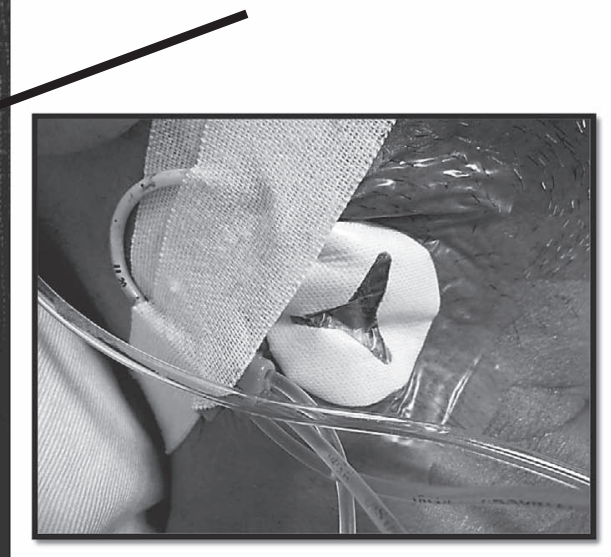

図 1 フィックスキット ${ }^{\circledR} \cdot \mathrm{CV}$

結合させた抗菌性繊維材料が開発され, 代表的な院内感 染細菌 (Staphylococcus aureus, Staphylococcus epidermidis, Pseudomonas aeruginosa など）に対する抗菌 効果に関する報告がされた ${ }^{11)}$. 今回, 抗菌効果のある亜 鉛結合繊維パッドを組み合わせたフィルムドレッシング 材の使用が, 中心静脈カテーテル挿入患者の刺入部周囲 皮膚細菌叢に及ぼす影響を検討したので報告する。

\section{材料と方法}

1. 材 料

亜鉛イオンを結合させた亜鉛化合物含有綿編物をパッ ドとしたパッド付きフィルムドレッシング材（フィック スキット ${ }^{\circledR} \cdot \mathrm{CV}$ ) (図1) と, 従来から使用している滅 菌透明フィルムドレッシング材（従来ドレッシング）を 使用した。

\section{2. 対 象}

調査期間中に, 循環器病棟 (循環器内科, 心臓外科混 合病棟), 消化器内科病棟に入院中の中心静脈カテーテ ルを留置している患者で, 本人または家族の同意が得ら れた成人とした。

\section{3. 方 法}

カテーテル挿入部の消毒は, 当院のマニュアルに従い $10 \%$ ポビドンヨード液を用い, ドレッシング材で覆う 範囲よりも広範囲に消毒し 2 分間放置後にドレッシング 材を貼用した。

循環器病棟では, 2012 年 2 月〜 5 月は従来ドレッシン グ材， 6 月〜 1 月にフィックスキット ${ }^{\circledR} \cdot \mathrm{CV}$ を使用，消 化器病棟では, 2012 年 1 月〜 5 月はフィックスキット ${ }^{\circledR}$. $\mathrm{CV}, 6$ 月〜 12 月に従来ドレッシング材を使用するよう に割り当て, 検体を収集した。
カテーテル刺入部をあらかじめ割りつけられたドレッ シング材にて被覆した。

ドレッシング材除去直後にカテーテル挿入部を中心と し, 周辺部皮膚 $1 \mathrm{~cm}^{2}$ 程度の範囲を $0.05 \mathrm{~mL}$ の滅菌生理 食塩水を含んだ咸菌綿棒で擦過し，検体を採取した。採 取した検体を滅菌生理食塩水を用いて希釈し，5\% 羊血 液寒天培地を用いて $37^{\circ} \mathrm{C}$, 48 時間定量培養をした。

2012 年 1 月〜 2013 年 1 月の間に, 104 名の患者から 202 検体 (フィックスキット ${ }^{\circledR} \cdot \mathrm{CV}$ は 51 名 102 検体, 従 来ドレッシング材は 53 名 100 検体）を採取し，フィッ クスキット ${ }^{\circledR} \cdot \mathrm{CV}$ 群と従来ドレッシング群との（1）コ ロニー形成の有無と（2）細菌数を比較した.

1) 細菌学的検討

（1）コロニー形成の有無

細菌検出の基準を刺入部周囲皮膚に細菌によるコロ ニー形成がない場合には「検出なし」, コロニー形成が $1 \mathrm{cfu} / \mathrm{cm}^{2}$ 以上ある場合には「検出あり」とした。

\section{(2) 細菌数}

定量培養で得られた細菌数 $\left(\mathrm{cfu} / \mathrm{cm}^{2}\right)$ を比較した.さ らに, $10^{3} \mathrm{cfu} / \mathrm{cm}^{2}$ を超えると, カテーテル切片での細 菌検出率が有意に上昇するとの報告 ${ }^{4)}$ があるため $10^{3}$ $\mathrm{cfu} / \mathrm{cm}^{2}$ をカッオフ值としてそれぞれのドレッシング 材の比較も行った。

\section{2）患者背景}

コロニー形成, 細菌数に影響を及ぼす因子として(1)年 歯令, (2)性別, (3)診療科 (消化器内科, 心臓外科, 循環器 内科), (4)手術の有無, (5)挿入部位 (鎖骨下, 内頸, 大 腿), (6)カーテルの種類（シングル，ダブル，トリプ ル)，(7)貼付期間， (8body mass index $\left(B M I: \mathrm{kg} / \mathrm{m}^{2}\right)$, (9)血清アルブミン值 (albumin：ALB), (10血糖值, (11) 
表 1 患者背景

\begin{tabular}{|c|c|c|c|c|c|}
\hline & \multicolumn{2}{|c|}{$\begin{array}{c}\text { フィックスキット® } \\
\text { CV }\end{array}$} & \multicolumn{2}{|c|}{ 従来ドレッシング } & \multirow{2}{*}{$\mathrm{P}$ 值 } \\
\hline & 対象数 & 平均值 & 対象数 & 平均値 & \\
\hline 年齢 & 102 & 69.2 & 100 & 69.1 & 0.976 \\
\hline 貼付日数 & 102 & 4.7 & 100 & 4.2 & 0.13 \\
\hline BMI & 102 & 20.4 & 100 & 22.1 & 0.049 \\
\hline ALB & 102 & 3 & 100 & 3 & 0.801 \\
\hline 血糖值 & 102 & 142 & 100 & 145.6 & 0.729 \\
\hline \multirow[t]{2}{*}{ 体温 } & 102 & 37.4 & 100 & 37.2 & 0.009 \\
\hline & 対象数 & 頻度 & 対象数 & 頻度 & \\
\hline 性別（女性症例数） & 102 & 16 & 100 & 20 & 0.423 \\
\hline 診療科（消化器内科） & 102 & 51 & 100 & 49 & 0.887 \\
\hline 診療科（心臟外科） & 102 & 35 & 100 & 45 & 0.121 \\
\hline 診療科（循環器内科） & 102 & 16 & 100 & 6 & 0.027 \\
\hline 手術（あり） & 102 & 35 & 100 & 50 & 0.023 \\
\hline 挿入部位（鎖骨下） & 102 & 3 & 100 & 3 & $>0.999$ \\
\hline 挿入部位（内頝） & 102 & 83 & 100 & 90 & 0.08 \\
\hline 挿入部位（鼠径） & 102 & 16 & 100 & 7 & 0.052 \\
\hline カテ種類 (シングル) & 102 & 40 & 100 & 39 & 0.974 \\
\hline カテ種類（ダブル） & 102 & 21 & 100 & 3 & $<0.001$ \\
\hline カテ種類 (トリプル) & 102 & 41 & 100 & 57 & 0.017 \\
\hline
\end{tabular}

表 2 CRBSI 発生率

\begin{tabular}{lcc}
\hline & フィックスキット ${ }^{\circledR} \cdot \mathrm{CV}$ & 従来ドレッシング \\
\hline 感染数 & 1 & 0 \\
延べカテーテル日数 & 681 & 715 \\
感染率 & 1.5 & 0 \\
\hline 感染率＝感染数/延ベカテーテル日数 $\times 1000$ &
\end{tabular}

体温, (12)皮膚所見（発赤, びらん）の有無の 12 項目に ついて比較した.

血清アルブミン值は，ドレッシング材貼用から交換ま での間に得られた值，または最も近い日の值．血糖は， ドレッシング材貼用から交換までの間に得られた最も高 い值，または，最も近い日での最も高い值を用いた。体 温は，ドレッシング材貼用から交換までの間で最も高い 值を用いた。

\section{3）統計解析}

統計解析には，統計解析ソフト（SPSS IBM）を用い た. 統計解析手法として, 従属変数を（1）コロニー形 成の有無, (2) 細菌数 $\left(\mathrm{cfu} / \mathrm{cm}^{2}\right)$ として, 前者（1）を ロジスティック回帰分析, 後者 (2) を重回帰分析にて 上記患者背景の情報を独立変数としてステップワイズ増 減法を用いて解析した。 また, ドレッシング材の違いに よる菌の検出の有無にはカイ 2 乗検定を行い $p<0.05$ を 有意とした.

CRBSI の診断は，米国疾病予防管理センター $(\mathrm{CDC})$ の National Healthcare Safety Network (NHSN) の診
断基準を用いた ${ }^{13}$.

本研究は研究方法について施設の倫理委員会の了承を 得た（倫理委員会承認番号 23-18）.

結果

患者背景を表 1 に示した. BMI, 体温, 循環器内科, 手術あり, カテ種類(ダブル, トリプル)において, フィッ クスキット ${ }^{\circledR} \cdot \mathrm{CV}$ 群と従来ドレッシング群では統計学 的な有意差を認めた。

調査期間中の CRBSI の発生は, フィックスキット ${ }^{\circledR}$. $\mathrm{CV}$ 使用時に 1 件認めたが, ドレッシング間で感染率に は有意差を認めなかった（表 2).

\section{I 、コロニー形成の有無}

刺入部周囲皮膚のコロニー形成は，全体の $54.5 \%$ に みられた。細菌「検出あり」の割合は循環器病棟 $57.8 \%$ と消化器病棟 $51.0 \%$ で病棟間の有意差はなかった。

ドレッシング剤での比較では, 細菌「検出あり」が, フィックスキット ${ }^{\circledR} \cdot \mathrm{CV}$ 群 $47.1 \%$, 従来ドレッシング 群では $62.0 \%$ と, フィックスキット・ ${ }^{\circledR} \cdot \mathrm{CV}$ 群の方が細 
表 3 細菌数に影響を及ぼす因子

細菌の検出あり群と検出なし群とのロジスティック回帰分析

\begin{tabular}{|c|c|c|c|c|}
\hline & \multirow{2}{*}{ 有意確率 } & \multirow{2}{*}{ オッズ比 } & \multicolumn{2}{|c|}{ 95\% 信頼区間 } \\
\hline & & & 下限 & 上限 \\
\hline テープ種類 & .388 & .750 & .391 & 1.441 \\
\hline 年齢 & .702 & 1.005 & .981 & 1.029 \\
\hline 性別 & .011 & 3.089 & 1.297 & 7.357 \\
\hline 手術 & .804 & 1.264 & .199 & 8.036 \\
\hline 貼付期間_日 & .387 & .933 & .796 & 1.092 \\
\hline 皮膚所見 & .006 & 3.469 & 1.420 & 8.477 \\
\hline BMI & .060 & 1.098 & .996 & 1.209 \\
\hline ALB & .769 & 1.109 & .555 & 2.216 \\
\hline 血糖 & .551 & 1.002 & .996 & 1.008 \\
\hline BSI & 1.000 & .000 & .000 & . \\
\hline 体温 & .112 & .684 & .429 & 1.092 \\
\hline 診療科 ～～～～～～～ & .694 & 1.238 & .427 & 3.592 \\
\hline カテーテル挿入部位 & .124 & 2.222 & .803 & 6.145 \\
\hline カテーテル種類 & .612 & .847 & .447 & 1.606 \\
\hline
\end{tabular}

BMI : Body Mass Index ALB : 血清アルブミン值 BSI : Bloodstream Infection

表 4 細菌検出に影響する因子

細菌の検出あり群と検出なし群とのロジスティック回帰分析

\begin{tabular}{lcrrr}
\hline & \multirow{2}{*}{ 有意確立 } & オッズ比 & \multicolumn{2}{c}{$95 \%$ 信頼区間 } \\
\cline { 4 - 5 } & & & 下限 & \multicolumn{1}{c}{ 上限 } \\
\hline 性別 & 0.001 & 6.936 & 2.168 & 22.192 \\
皮膚所見 & 0.017 & 2.842 & 1.202 & 6.716 \\
BMI & 0.002 & 1.420 & 1.141 & 1.767 \\
カテーテル挿入部位 & 0.020 & 3.057 & 1.196 & 7.811 \\
\hline
\end{tabular}

細菌検出あり，なしに影響する因子としては，皮膚所見が最も高く (6.936 倍), ついで, BMI (1.420 倍), カテーテル挿入部位 (3.057

倍）であり，ドレッシング剤は影響しないことが判明した。

（※性別は女性の例数が少なすぎ偏りが大きいため削除）

菌検出率は有意に低かった $(p<0.03)$.

細菌検出の「検出あり」,「検出なし」に影響する有意 な因子としては, 単変量解析では, 性別 (3.089 倍), 皮 膚所見（3.469 倍）であった（表 3). 多変量解析によれ ば，性別（6.936 倍), 皮膚所見 (2.84 倍), BMI (1.420 倍), カテーテル挿入部位（3.057 倍）であり，ドレッシ ング材の違いは, 細菌検出に関連していなかった（表 4). 多変量解析で細菌検出に影響があるとされた BMI を, 日本糖尿病学会により肥満と規定されている BMI 25 $\mathrm{kg} / \mathrm{m}^{2}$ をカットオフ值とし, 細菌「検出あり」の割合を みると, BMI $25 \mathrm{~kg} / \mathrm{m}^{2}$ 未満では $50.6 \%$, BMI $25 \mathrm{~kg} / \mathrm{m}^{2}$ 以上では $73.5 \%$ と BMI $25 \mathrm{~kg} / \mathrm{m}^{2}$ 以上の方が細菌検出率 は有意に高かった $(p<0.01)$. BMI $25 \mathrm{~kg} / \mathrm{m}^{2}$ 以上の患 者が占める割合が, フィックスキット ${ }^{\circledR} \cdot \mathrm{CV}$ 群 $9.8 \%$ に 比べ従来ドレッシング群の方が $24.0 \%$ と有意に高かっ た $(p<0.007)$ ため, この偏りが, フィックスキット ${ }^{\circledR}$. $\mathrm{CV}$ 群の細菌検出割合を低くする要因になる可能性があ
ると判断し, BMI $25 \mathrm{~kg} / \mathrm{m}^{2}$ 以上の患者を除いて, 細菌 の「検出あり」,「検出なし」の比較も行ったが, BMI 25 $\mathrm{kg} / \mathrm{m}^{2}$ 未満での細菌の「検出あり」の割合は, フィック スキット ${ }^{\circledR} \cdot \mathrm{CV}$ 群 $43.5 \%$, 従来ドレッシング群 $59.2 \%$ と, フィックスキット ${ }^{\circledR} \cdot \mathrm{CV}$ 群の方が低かった $(p<$ 0.04). なお, BMI のカットオフ值 $23 \mathrm{~kg} / \mathrm{m}^{2}$ とすると細 菌検出率に有意差を認めなかった.

皮膚所見のある割合は, フィックスキット ${ }^{\circledR} \cdot \mathrm{CV}$ 群 $19.6 \%$, 従来ドレッシング群が $26.0 \%$ であり有意差はな く，皮膚所見がある場合の細菌「検出あり」の割合も フィックスキット ${ }^{\circledR} \cdot \mathrm{CV}$ 群 $83.3 \%$, 従来ドレッシング 群が $73.1 \%$ とドレッシング間に有意差を認めなかった。

\section{II. 細菌数}

細菌数の最大数は, フィックスキット ${ }^{\circledR} \cdot \mathrm{CV}$ が $4.0 \times$ $10^{8} \mathrm{cfu} / \mathrm{cm}^{2}$, 従来ドレッシングは $3.6 \times 10^{8} \mathrm{cfu} / \mathrm{cm}^{2}$ で, 平均はフィックスキット ${ }^{\circledR} \cdot \mathrm{CV}: 7.5 \times 10^{6} \mathrm{CFU} / \mathrm{cm}^{2}( \pm$ $\left.4.2 \times 10^{7} \mathrm{CFU} / \mathrm{cm}^{2}\right)$, 従来ドレッシング $1.7 \times 10^{7} \mathrm{CFU} /$ 


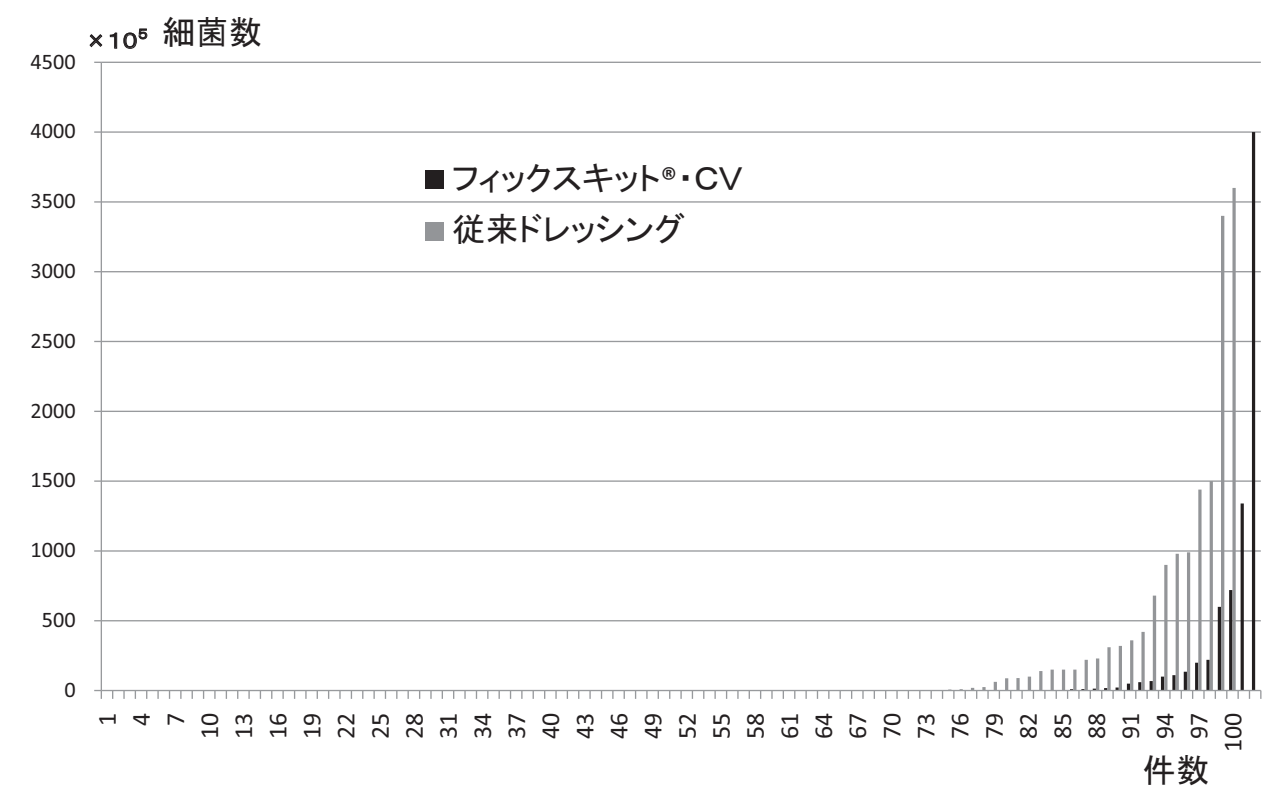

検出された細菌数

図 2 細菌数 $\left(\mathrm{CFU} / \mathrm{cm}^{2}\right)$

フィックスキット ${ }^{\circledR} \cdot \mathrm{CV}$; 平均 : $7.5 \times 10^{6} \mathrm{CFU} / \mathrm{cm}^{2} \pm 4.2 \times 10^{7} \mathrm{CFU} / \mathrm{cm}^{2}$

従来ドレッシング ; 平均 : $1.7 \times 10^{7} \mathrm{CFU} / \mathrm{cm}^{2} \pm 5.5 \times 10^{7} \mathrm{CFU} / \mathrm{cm}^{2}$

表 5 細菌数（生値）に影響を及ぼす因子

細菌数を従属変数とした重回帰分析

\begin{tabular}{lrrrrr}
\hline & \multirow{2}{*}{ 非標準化係数 B } & 標準化係数 $\beta$ & 有意確率 & \multicolumn{2}{c}{ B の 95\% 信頼区間 } \\
\cline { 5 - 6 } & & & & 下限 & \multicolumn{1}{c}{ 上限 } \\
\hline (定数) & -40878312.765 & & 0.005 & -69368716.128 & -12387909.401 \\
BMl & 2192683.940 & 0.223 & 0.001 & 874345.534 & 3511022.646 \\
皮膚所見 & 18806479.891 & 0.192 & 0.005 & 5633627.125 & 31979332.657 \\
\hline
\end{tabular}

細菌数 $($ 生值 $)=-40878312.765+(2192683.940 \times \mathrm{BMI})+(18806479.891 \times$ 皮膚所見 $)$

$\mathrm{R}: 0.306$

表 6 細菌数（生値）に影響を及ぼす因子 (BMI $25 \mathrm{Kg} / \mathrm{m}^{2}$ 未満)

細菌数を従属変数とした重回帰分析

\begin{tabular}{|c|c|c|c|c|c|}
\hline & \multirow{2}{*}{ 非標準化係数 B } & \multirow{2}{*}{ 標準化係数 $\beta$} & \multirow{2}{*}{ 有意確率 } & \multicolumn{2}{|c|}{ B の 95\% 信頼区間 } \\
\hline & & & & 下限 & 上限 \\
\hline （定数） & 299959508.371 & & 0.015 & 59356085.466 & 540562931.277 \\
\hline 皮膚所見 & 15060043.101 & 0.199 & 0.009 & 3745178.674 & 26374907.528 \\
\hline 体温 & -7957263.885 & -0.184 & 0.016 & -14408876.119 & -1505651.650 \\
\hline
\end{tabular}

$\mathrm{cm}^{2}\left( \pm 5.5 \times 10^{7} \mathrm{CFU} / \mathrm{cm}^{2}\right)$ であった（図 2).

細菌数 $10^{3} \mathrm{cfu} / \mathrm{cm}^{2}$ をカットオフ值として，それぞれ のドレッシング材を比較した結果, 細菌数が $10^{3} \mathrm{cfu} / \mathrm{cm}$ ${ }^{2}$ 以下となったのは, フィックスキット ${ }^{\circledR} \cdot \mathrm{CV}$ 群 $67.6 \%$, 従来ドレッシング群では $58.0 \%$ であり, フィックスキッ ト ${ }^{\circledR} \cdot \mathrm{CV}$ 群の割合が大きかったが, 有意ではなかった $(p>0.05)$.
細菌数に影響を及ぼす因子として, 細菌数を従属変数 とした重回帰分析では，皮膚所見と BMI があげられ，ド レッシング材は影響はなかった（表 5). BMI $25 \mathrm{~kg} / \mathrm{m}^{2}$ 未満を対象とし, 細菌数を従属変数とした重回帰分析で は, BMI $25 \mathrm{~kg} / \mathrm{m}^{2}$ 未満でも細菌数に影響を与える因子 としては, 皮膚所見と体温があげられ（表 6), ドレッ シング材は, 細菌数には影響していなかった。 


\section{考察}

今回，亜鉛結合繊維パッドが CRBSI 発生率に与える 影響について検討した。しかし，調査期間中の CRBSI 発生は，1例だけであり統計的有意差を認めるには至ら なかった，さらに, CRBSI を発生した 1 例は, CV カテー テル挿入後 1 週間以内の発生であり，ドレッシング材の 違いによる影響はないと考えられる。

カテーテル挿入部周囲皮膚の細菌検出「あり」の割合 は，肥満とされる BMI $25 \mathrm{~kg} / \mathrm{m}^{2}$ 以上の患者では $73.5 \%$ と高い值を示した。肥満があると発汗とともに皮膚水分 奕失量も増加し, 皮膚の免疫機能が低下する ${ }^{14,15)}$. この ことより肥満による上皮バリアの変化が, 細菌を繁殖し やすくしていることが示唆された.

今回, 検出した細菌数が $4.0 \times 10^{7} \mathrm{cfu} / \mathrm{cm}^{2}$ でも CRBSI を発症しておらず, 皮膚細菌数と CRBSI 発生との関係 性については明らかではなかったが, 挿入部の皮膚から 検出された細菌数が $10^{3} \mathrm{cfu} / \mathrm{cm}^{2}$ を超えると, カテーテ ル切片での細菌検出率が有意に上昇するとの報告 ${ }^{2}$ があ るように, CRBSI 予防のためには, カテーテル刺入部 皮膚の細菌数を減少させることが重要と考えられる ${ }^{16)}$.

細菌形成が有意に上昇するとの報告 ${ }^{4)}$ のある, 細菌数 $10^{3} \mathrm{cfu} / \mathrm{cm}^{2}$ をットオフ值とした, フィックスキッ ト ${ }^{\circledR} \cdot \mathrm{CV}$ 群と従来ドレッシング群と比較すると, フィッ クスキット ${ }^{\circledR} \cdot \mathrm{CV}$ 群で, 細菌数 $10^{3} \mathrm{cfu} / \mathrm{cm}^{2}$ 以下を示す 割合が大きい傾向を示したが, 有意差は認められなかっ た. また, フィックスキット ${ }^{\circledR} \cdot \mathrm{CV}$ 群は, 従来ドレッ シング群と比較し, 有意に細菌「検出あり」の割合が低 い結果を示し, フィックスキット ${ }^{\circledR} \cdot \mathrm{CV}$ は, 中心静脈 カテーテル挿入部の細菌検出を減少させる効果があるこ とが示唆された。今回の検討により, 細菌検出に影響を 及ぼす因子としては，皮膚所見，BMI，体温，カテーテ ル挿入部位が挙げられ，ドレッシング材は有意な因子で はなかった。 この原因として本検討は, 検体採取を病棟 看護師が実施したため, ドレッシング交換時に検体が採 取されなかった場合のあること，長期カテーテルが挿入 されている患者では検体が繰り返し採取されたこと, な どがデーターに影響を与えた可能性は否定できない.

また, 挿入されているカテーテルの形状の影響で, フィックスキット ${ }^{\circledR} \cdot \mathrm{CV}$ の抗菌性繊維部分が, 皮膚に 密着しない場合があり, 十分な抗菌効果が発揮されな かった可能性も考えられる. 今後, 抗菌性繊維部分の皮 膚への密着度を上げ, 各ドレッシング使用群の対象者数 や採取検体数を増やすことにより, カテーテル感染発生 に対するドレッシング材の材質が及ぼす影響を評価する ことが望まれる。

抗菌作用を持つドレッシング材として, クロルヘキシ ジンゲルドレッシングが, 広く使われており, 皮膚の細 菌増殖を抑制する効果が報告されている
クロルヘキシジンによるアレルギーが問題となってお $り^{18 \sim 20)}$ ，クロルヘキシジンを用いたドレッシング材使用 例では, 成人で 5.3/1,000catheters の頻度で接触皮膚炎 を認めたとの報告や，低出生体重児では，15.3\%に接触 皮膚炎を合併したという報告もある ${ }^{4,12)}$ 。一方，銀を使 用したドレッシング材では，接触皮膚炎の発生は，認め られなかったとの報告もあり ${ }^{4)}$, 今回使用した亜鉛は, 銀 と同じ無機系の抗菌物質であるため, 安全性は高いと考 える11.

今回の研究で, 亜鉛化合物含有カテーテル被覆・保護 材の抗菌性が皮膚の細菌の増殖リスクを軽減する可能性 が示唆された。また，発汗が多く，皮膚の免疫機能が低 下した肥満患者への CV 管理方法の検討が必要であるこ とが示唆された。

利益相反自己申告：本研究は, アルケア株式会社からの受託研 究として愛知医科大学で実施されたものである. 吉田英二, はア ルケア株式会社の社員である.

加藤由紀子, 浜田幸宏, 久留宮愛, 岡前朋子, 高橋知子, 坂田 美樹, 末松寛之, 西山直哉, 小泉祐介, 山岸由佳, 三鴨廣繁につ いて利益相反はない.

\section{文献}

1) Shah H, Bosch W, Thompson KM, Hellinger WC: Intravascular Catheter-Related Bloodstream Infection. Neurohospitalist 2013; 3: 144-51.

2) Gahlot R, Nigam C, Kumar V, Yaday G, Anupurba S: Carheter-related bloodstream infections. Int J Crit Illn Sci 2014; 4: 162-7.

3) Safdar N, Kluger DM, Maki DG: A review of risk factors for catheter-related bloodstream infection caused by percutaneously inserted, noncuffed central venous catheters: implications for preventive strategies. Medicine (Baltimore) 2002; 81: 466-79.

4) Timsit JF, Dubois Y, Minet C, bonadona A, et al: New materials and devices for preventing catheter-related infection. Ann Intensive Care 2011; 1: 34.

5) Mermel A: What is the predominant source of intravascular catheter infections? Clin Infect Dis 2011; 52: 211-2.

6) Crnich CJ, Maki DG: The promise of novel technology for the prevention of intravascular device-related bloodstream infection. I. Pathogenesis and short-term devices. Clin Infect Dis 2002; 34: 1232-42.

7) Safdar N, Maki DG: The pathogenesis of catheter-related bloodstream infection with noncuffed short-term central venous catheters. Intensive Care Med 2004; 30: 62-7.

8) Rijinders BJ, Van Wijingaerden E, Peetermans WE: Catheter-tip colonization as a surrogate end point in clinical studies on catheter-related bloodstream infection: how strong is the evidence? Clin infect Dis 2002; 35: 1053-8.

9) Bjornson HS, Colley R, Bower RH, Duty VP, SchwartzFluton JT, Fischer JE: Association between microorganism growth at the catheter insertion site and colonization of the catheter in patients receiving total parenteral nutrition. Surgery 1982; 92: 720-7.

10) Dobbins BM, kite P, Kindon A, Mcmahon MJ, Wilcox MH: DNA fingerprinting analysis of coagulase negative staphy- 
lococci implicated in catheter related bloodstream infections. J Clin Pathol 2002; 55: 824-8.

11）野中栄治, 中村博昭, 岩菩徹治, 小林寅苦, 辻 明良: Carboxymethylcellulose-cethylpyridinium/zinc 瀻維の抗菌 効果. 日本環境感染学会誌 2009; 24: 93-9.

12) Levy I, Katz J, Solter E, Samra Z, Vidne B, Birk E, et al.: Chlorhexidin-impregnated dressing for prevention of colonization of central venous catheters in infants and children. Pediatr Infect Dis J 2005; 24: 676-9.

13) Horan TC, Andrus M, Dudeck MA: CDC/NHSN surveillance definition of health care-associated infection and criteria for specific types of infection in the acute care setting. Am J Infect Control 2008; 36: 309-32.

14) Nino M, Franzese A, Ruggiero Perrino N, Balato N: The effect of obesity on skin disease and epidermal permeability barrier status in children. Pediatric Dermatology 2012; 29: 567-70.

15) Cheung KP, Taylor KR, Jameson JM: Immunomodulation at epithelial sites by obesity and metabolic disease. Immu- nol Res 2012; 52: 182-99

16）谷村久美，大久保憲：血管内留置カテーテル挿入部位の皮 虐消毒に関する検討. 環境感染学会誌 2010; 25: 281-5.

17) Karpanen TJ, Casey AL, Conway BR, Lambert PA, Elliott TS: Antimicrobial activity of a chlorhexidine intravascular catheter site gel dressing. Antimicrob Chemother 2011; 66: 1777-84.

18) Abdallah C: Perioperative Chlorhexidine allergy: Is it serious? J Anaesthesiol Clin Pharmacol 2015; 31: 152-4.

19) Hong CC, Wang SM, Nathe A, Tan JH, Tay SH, Poon KH: Chlorhexidine Anaphylaxis Masquerading as Septic shock. Int Arch Allergy Immunol 2015; 167: 16-20.

20) Opstrup MS, Johansen JD, Garvey LH: Chlorhexidine allergy: sources of exposure in the health-care setting. $\mathrm{Br} \mathrm{J}$ Anaesth 2015; 114: 704-5.

〔連絡先：〕480-1195 愛知県長久手市岩作雁又 1-1 愛知医科大学病院感染制御部感染管理室 加藤由紀子 E-mail: a102192@aichi-med-u.ac.jp]

\title{
Antimicrobial Effect of Film Dressing for Skin around the Catheter Insertion Site
}

\author{
Yukiko KATO $^{1)}$, Yukihiro HAMAdA ${ }^{1)}$, Ai KURUmiYA ${ }^{1)}$, Tomoko OKAmAE ${ }^{1)}$, Tomoko TAKAHAshi ${ }^{1)}$, \\ Miki SAKATA $^{1)}$, Hiroyuki Suematsu' ${ }^{1}$, Eiji YoshidA ${ }^{2)}$, Naoya NishiYAmA ${ }^{1)}$, Yusuke KoIzUmi ${ }^{1}$, \\ Yuka YAMAGISHI ${ }^{1)}$ and Hiroshige MiKAMO ${ }^{1)}$
}

\footnotetext{
${ }^{1)}$ Department of Infection Control and Prevention, Aichi Medical University Hospital, Aichi, Japan, ${ }^{2)}$ ALCARE Co., Ltd, Tokyo, Japan
}

\section{Abstract}

It is clear that bacterial flora of skin around the catheter insertion site would be associated with catheter related bloodstream infection (CRBSI). We evaluated the antibacterial effect of film dressings including Fixkit ${ }^{\circledR} \cdot \mathrm{CV}$ (ALCARE Co., Ltd. Tokyo, Japan), which was composed of a transparent film adhesion material and an antibacterial pad with zinc, for skin around the catheter insertion site. We compared the antibacterial film dressing Fixkit ${ }^{\circledR} \mathrm{CV}$ and non-zinc contained film dressing as randomized control trial in the Aichi Medical University Hospital. The protocol was reviewed and approved by a local institutional committee, and written informed consents were obtained before enrolling. Two hundred and two patients with central venous catheter were enrolled in this study; 102 for Fixkit ${ }^{\circledR} \cdot \mathrm{CV}$ and 100 for non-antibacterial film dressing. We performed a quantitative microbial examination for a skin area of $1 \mathrm{~cm}^{2}$ around the catheter insertion site after removing the dressing films. The rates of positive bacterial detection for Fixkit ${ }^{\circledR} \cdot \mathrm{CV}$ and non-antibacterial film dressing were $47.1 \%$ and $62.0 \%$, respectively $(p=0.03)$. According to logistic regression analysis, body mass index (BMI), gender, and insertion site of central venous catheter $(\mathrm{CVC})$ were significant factors to isolate bacteria from the skin around the catheter insertion site. Positive bacterial detection rates between patients with BMI $>25$ and $<25$ were $73.8 \%$ and $49.4 \%$, respectively $(p=0.01$ ). BMI was the most important factor for the number of bacteria of skin around the catheter insertion site. We conclude that antimicrobial dressings such as antibacterial pad with zinc would be able to decrease the risk of skin colonization around the catheter insertion site in patients with $\mathrm{BMI}<25$.

Key words: antibacterial film dressing, central vascular catheter, skin bacterial flora 